\title{
Energy-dependence of the Assimilatory Nitrate Uptake in Azotobacter chroococcum
}

\author{
By ELISA REVILLA, $\dagger$ ANTONIO LLOBELL $\ddagger$ AND \\ ANTONIO PANEQUE* \\ Departamento de Bioquimica, Facultad de Biología y CSIC, Apartado 1095, 41080 Sevilla, Spain
}

(Received 17 June 1985 ; revised 28 October 1985)

Nitrate assimilation by suspensions of Azotobacter chroococcum, as determined by the disappearance of the ion from the external medium, displayed saturation kinetics, was inhibited by nitrite, and exhibited an affinity for nitrate higher than that of nitrate reductase. This suggests that the entry of nitrate into the cell is mediated by a specific transporter. Nitrate assimilation required a readily utilizable carbon source and aerobic conditions and was blocked by the uncouplers carbonyl cyanide $p$-trifluoromethoxyphenylhydrazone (FCCP) and 2,4dinitrophenol (DNP) but not by $N, N^{\prime}$-dicyclohexylcarbodiimide (DCCD), an inhibitor of ATPases. The inhibition of nitrate assimilation in the absence of an appropriate carbon source was overcome by the non-physiological energy source ascorbate plus $N$-methylphenazinium methylsulphate (PMS), a substrate combination that allowed respiration. Though an ATPdependent nitrate uptake mechanism cannot be ruled out, these data suggest that transport of nitrate into the cell is directly dependent on the proton electrochemical gradient across the cytoplasmic membrane.

\section{INTRODUCTION}

The process of nitrate assimilation comprises at least three consecutive steps: uptake, followed by reduction of nitrate and incorporation of the reduced nitrogen into carbon skeletons. In micro-organisms that accumulate nitrate, for example the diatoms Phaeodactylum tricornutum (Cresswell \& Syrett, 1981) and Skeletonema costatum (Serra et al., 1978) and the fungus Neurospora crassa (Schloemer \& Garrett, 1974), nitrate uptake and its subsequent metabolism can be distinguished by measuring both nitrate disappearance from the medium and intracellular nitrate. It has been proposed that transport of nitrate into these cells is an ATPdependent process (Cresswell \& Syrett, 1981; Falkowski, 1975).

In unicellular micro-organisms that lack storage vacuoles, and are thus unable to accumulate nitrate, separation of nitrate uptake from its subsequent assimilatory reduction is not possible unless the short half-life isotope ${ }^{13} \mathrm{~N}$ is used. Studies of Klebsiella pneumoniae (Thayer \& Huffaker, 1982) and Pseudomonas fluorescens (Betlach et al., 1981) have shown, using ${ }^{13} \mathrm{NO}_{3}^{-}$, that cells accumulate nitrate internally and that, in the case of $K$. pneumoniae, one of the two transport systems must be active. However, the energy requirements of the uptake process were not described in either case.

We have previously reported on the conditions required for the development of assimilatory nitrate uptake in the strictly aerobic, heterotrophic bacterium Azotobacter chroococcum (Revilla

† Present address: Departamento de Bioquimica, Facultad de Farmacia, Universidad de Sevilla, Sevilla, Spain. Spain.

† Present address: Departamento de Bioquímica, Facultad de Veterinaria, Universidad de Córdoba, Córdoba,

Abbreviations: CCCP, carbonyl cyanide $m$-chlorophenylhydrazone; $\mathrm{DCCD}, N, N^{\prime}$-dicyclohexylcarbodiimide; DNP, 2,4-dinitrophenol: FCCP, carbonyl cyanide $p$-trifluoromethoxyphenylhydrazone; PMS, $N$-methylphenazinium methylsulphate. 
et al., 1985). We now present data indicating the existence in this organism of an active transport mechanism for nitrate which seems to be directly dependent on the proton electrochemical gradient across the cytoplasmic membrane.

\section{METHODS}

Chemicals. MOPS and PMS were purchased from Sigma; FCCP was from Boehringer; DNP, DCCD and all other chemicals were of analytical grade and were acquired from Merck.

Organism and culture conditions. A. chroococcum (strain ATCC 4412 from the Valencia University Collection) was used throughout. Maintenance of stock cultures and preparation of liquid cultures with nitrate as the nitrogen source were as previously described (Paneque et al., 1982). Where indicated, mannitol (the carbon and energy source) was replaced by $0.5 \%(\mathrm{w} / \mathrm{v})$ glucose or succinate, or by $1 \%(\mathrm{w} / \mathrm{v})$ pyruvate, ethanol or acetate.

Measurement of nitrate uptake. Mid-exponential phase cells $\left(\mathrm{OD}_{650}\right.$ approximately 0.5$)$ were used for each experiment. Cultures were harvested by centrifugation at $8000 \mathrm{~g}$ for $10 \mathrm{~min}$ at $4^{\circ} \mathrm{C}$, washed twice with $25 \mathrm{mM}$ MOPS/KOH buffer ( $\mathrm{pH} 7.5$ ), and resuspended to $0.4-0.5 \mathrm{mg}$ cell protein $\mathrm{ml}^{-1}$ in the same buffer $(50 \mathrm{~mm})$ supplemented with $2 \%(\mathrm{w} / \mathrm{v})$ mannitol. Where indicated, mannitol was replaced by the specified substrate as the energy source. Assays were done with continuous shaking at $27^{\circ} \mathrm{C}$ in conical flasks open to the air or, for anaerobic assays, in closed flasks containing Ar as the gas phase. The experiments were started by the addition of $\mathrm{KNO}_{3}$ (0.3-0.5 mM final concentration) and, at intervals thereafter, nitrate uptake was assayed by following the disappearance of nitrate from the medium after rapid removal of bacteria by filtration in a Millipore system with Whatman glass microfibre paper. All the results are representative of three separate experiments on different batches of bacteria.

Analytical procedures. Nitrate reductase activity was determined in situ as follows: $5 \mathrm{ml}$ cell suspension was centrifuged at $9750 \mathrm{~g}$ for $5 \mathrm{~min}$ at $4{ }^{\circ} \mathrm{C}$, washed once with $25 \mathrm{mM}$-MOPS/KOH buffer (pH 7.5), and resuspended to 2-4 $\mathrm{mg}$ cell protein $\mathrm{ml}^{-1}$ in $1 \mathrm{ml}$ of the same buffer $(125 \mathrm{mM})$ supplemented with $0.25 \mathrm{mM}$-EDTA. Toluene $(20 \mu \mathrm{l})$ was added and the mixture vigorously shaken for $2 \mathrm{~min}$. A sample of this suspension was added to the reaction mixture for nitrate reductase activity with dithionite-reduced methyl viologen as the electron donor (Guerrero et al., 1973). Activity units correspond to $\mu \mathrm{mol}$ nitrite produced $\mathrm{min}^{-1}$. Glutamine synthetase was determined in cells permeabilized with alkyltrimethylammonium bromide mixture (Cejudo et al., 1984) by the $\gamma$-glutamyl transferase assay at $\mathrm{pH} 7.5$ (Shapiro \& Stadtman, 1970). Nitrate was determined spectrophotometrically at $210 \mathrm{~nm}$ in acid solution (Cawse, 1967) after eliminating, when necessary, ascorbate by heating at $80^{\circ} \mathrm{C}$ for $10 \mathrm{~min}$ with alkali (Katoh, 1963). Nitrite was estimated by the method of Snell \& Snell (1949). Oxygen consumption by $A$. chroococcum cells was followed with a Hansatech oxygen electrode equipped with a Varian recorder.

\section{RESULTS AND DISCUSSION}

\section{Effect of external nitrate concentration on nitrate assimilation}

To study whether nitrate uptake in $A$. chroococcum is mediated by an active transport process, the effect of various external nitrate concentrations on the rate of nitrate uptake was investigated. The rate remained constant within the range $0 \cdot 1-1 \mathrm{~mm}$ and was inhibited at higher concentrations (not shown). When the initial external nitrate concentration was $0.1 \mathrm{~mm}$ the rate of uptake was constant until the concentration of nitrate in the medium reached approximately $40 \mu \mathrm{M}$ (Fig. 1). Hence the half-saturation constant of the nitrate assimilation system must be lower than $40 \mu \mathrm{M}$.

Since the consumption of nitrate by $A$. chroococcum depends on the entry of the ion into the cell and on its subsequent reduction and assimilation of the ammonium produced, the simplest way to interpret the results shown in Fig. 1 is that assimilation of nitrate by this bacterium displays saturation kinetics and has an affinity for nitrate higher than that estimated in vitro $(0.25 \mathrm{mM})$ for nitrate reductase (Guerrero et al., 1973). As discussed by Hayashi \& Lin (1965), this difference in affinity is presumptive evidence for the existence of an active transport.

The $K_{\mathrm{m}}$ value for nitrate $(0.25 \mathrm{mM})$ of $A$. chroococcum nitrate reductase was obtained with viologen dyes as the reducing substrate, and recently Morpeth \& Boxer (1985) have reported a $K_{\mathrm{m}}$ for nitrate of the purified nitrate reductase from Escherichia coli of $2 \mu \mathrm{M}$ when quinols (analogues of the physiological reductant) are oxidized, as compared to $0.42 \mathrm{~mm}$ with reduced viologen dyes as the electron donor. Therefore, $A$. chroococcum nitrate reductase could exhibit a higher affinity for nitrate in vivo. Although not accurately measured, the half-saturation concentratical for nitrate of the uptake process in $A$. chroococcum approaches those of other 


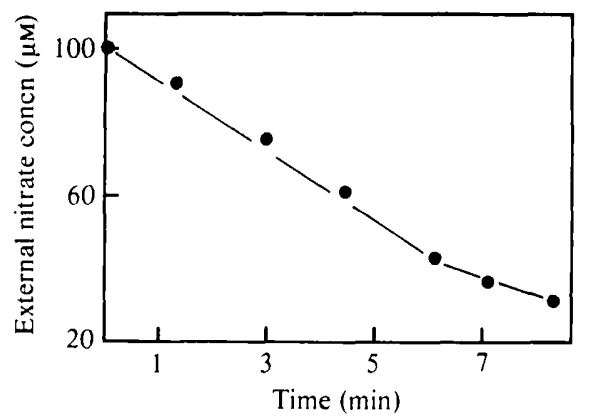

Fig. 1. Utilization of limiting amounts of nitrate by $A$. chroococcum. Cell suspensions $(0.4 \mathrm{mg}$ protein $\mathrm{ml}^{-1}$ ) were assayed for nitrate uptake as described in Methods except that the initial concentration of $\mathrm{KNO}_{3}$ was $0 \cdot 1 \mathrm{mM}$.

micro-organisms, which lie within the range $0 \cdot 1-10 \mu \mathrm{M}$ (Syrett, 1981; Ullrich, 1983; Thayer \& Huffaker, 1982; Betlach et al., 1981).

\section{Effect of external nitrite concentration on nitrate assimilation}

Nitrite, which was previously found to act as an inducer of assimilatory nitrate uptake (Revilla et al., 1985), strongly inhibited nitrate assimilation ( $79 \%$ inhibition at $0.3 \mathrm{~mm}$-nitrite increasing to a maximum of $96 \%$ at $0.5 \mathrm{~mm}$-nitrite). Nitrite was taken up by the cells irrespective of the presence of nitrate (as measured by following nitrite disappearance from the medium), at a rate which was practically the same as that of nitrate assimilation $\left[20-30 \mathrm{nmol}(\mathrm{mg} \text { protein })^{-1}\right.$ $\min ^{-1}$ ]. The decrease in nitrate utilization caused by nitrite was partly counteracted by nitrite consumption, the total amount of inorganic nitrogen taken up being almost the same in the presence of nitrate alone $(290 \mathrm{nmol})$ as with nitrate plus nitrite (53 and $204 \mathrm{nmol}$, respectively). By contrast, ammonium ( $0.3 \mathrm{~mm})$ totally inhibited nitrate assimilation (Revilla et al., 1985). Nitrite inhibition of nitrate uptake was not prevented by L-methionine-DL-sulphoximine, a glutamine synthetase inhibitor which releases nitrate assimilation from ammonium inhibition (Revilla et al., 1985).

From these results we propose that the passage of nitrate across the cell envelope is mediated by a protein with a high degree of specificity for the ion. In algae (Ullrich, 1983), as well as in Neurospora crassa (Schloemer \& Garrett, 1974), nitrate uptake and nitrite uptake do not proceed via the same carrier.

\section{Effect of energy source on nitrate assimilation}

The requirement of a readily usable carbon source for assimilatory nitrate uptake was investigated. When the cells were incubated in the nitrate uptake assay mixture that lacked a carbon source, there was no assimilation of nitrate (Table 1). Under anaerobic conditions, nitrate was not taken up even when a carbon source was available. In general, cells consumed nitrate at the highest rates when assayed in the presence of the carbon compound used for growth (Table 1). However, when cells that had been grown with mannitol were assayed in a medium with a different carbon source, nitrate uptake was either very low or absent (Table 1). Glucose was a striking exception, being more efficient than mannitol itself. No significant change in nitrate and nitrite reductase activities was detected when the cells grown in the standard mannitol/salts medium were suspended in media with different carbon sources (data not shown). Metabolic energy is therefore required for the assimilation of nitrate in $A$. chroococcum. When transferred to a new substrate, the slow induction or derepression of the appropriate enzyme(s) may be the cause of the low rates of nitrate uptake observed. In favour of this interpretation is the fact that cells grown on mannitol were unable to respire aerobically using succinate. Since enzymes for glucose utilization are constitutive, glucose was always the better substrate after transfer of the cells from mannitol. 


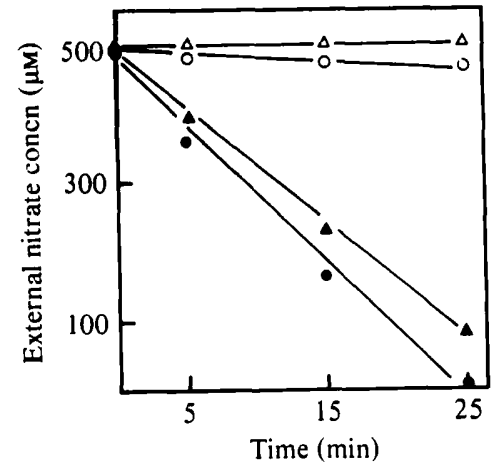

Fig. 2. Effect of metabolic inhibitors on nitrate uptake by $A$. chroococcum. Cells $\left(0.5 \mathrm{mg}\right.$ protein $\left.\mathrm{ml}^{-1}\right)$ were preincubated in the absence of additions $(O)$ and in the presence of $25 \mu \mathrm{M}-\mathrm{FCCP}(\triangle), 1 \mathrm{mM}-\mathrm{DNP}$ (O) or $100 \mu \mathrm{M}-\mathrm{DCCD}(\Delta)$ for $10 \mathrm{~min}$ before the nitrate $\left(0.5 \mathrm{~mm}-\mathrm{KNO}_{3}\right.$ added at zero time) utilization assay.

Table 1. Effects of growth conditions and of energy source on nitrate uptake rate by washed suspensions of $\boldsymbol{A}$. chroococcum

A. chroococcum cells were grown in media containing $0.5 \%(\mathrm{w} / \mathrm{v})$ mannitol $(\mathrm{A})$, and $0.5 \%(\mathrm{w} / \mathrm{v})$ glucose, $0.5 \%(\mathrm{w} / \mathrm{v})$ succinate, $1 \%(\mathrm{w} / \mathrm{v})$ pyruvate, $1 \%(\mathrm{w} / \mathrm{v})$ ethanol or $1 \%(\mathrm{w} / \mathrm{v})$ acetate $(B)$. Cells were harvested, washed and suspended as described in Methods, in the presence of the indicated energy source, and then incubated for $10 \mathrm{~min}$ before the nitrate uptake assay. The energy source concentration in the nitrate uptake assay was $20 \%$ of that used in the growth medium. The nitrate uptake rates are expressed as percentages of the rate of nitrate uptake by cells grown and assayed with mannitol as the carbon and energy source. A rate of $100 \%$ corresponded to $30 \mathrm{nmol}(\mathrm{mg} \text { protein })^{-1} \mathrm{~min}^{-1}$.

Growth medium

A. Mannitol

B. Glucose

Succinate

Pyruvate

Ethanol

Acetate
Energy source

during assay

None
Mannitol (anaerobically)
Mannitol
Glucose
Succinate
Pyruvate
Ethanol
Acetate
Glucose
Succinate
Pyruvate
Ethanol
Acetate

Relative rates of nitrate uptake $(\%)$

$$
\begin{array}{r}
0 \\
0 \\
100 \\
182 \\
0 \\
18 \\
0 \\
0 \\
278 \\
77 \\
42 \\
53 \\
50
\end{array}
$$

Additional evidence on the dependence of assimilatory nitrate uptake upon metabolic energy was obtained from studies with the uncouplers of oxidative phosphorylation FCCP (Padan et al., 1976) and DNP, the ATPase inhibitor DCCD (Harold et al., 1969) and the respiratory chain inhibitors azide and cyanide. Both FCCP (at $25 \mu \mathrm{M}$ final concentration) and DNP (1 mM) hindered the cells from utilizing nitrate, whereas DCCD $(100 \mu \mathrm{M})$ caused only a slight decrease (Fig. 2). To check whether the effect of FCCP and DNP on nitrate consumption was due to inhibition of the nitrate-reducing enzymic system, nitrate and nitrite reductase activities were determined in situ at zero time and 25 min after initiation of the nitrate uptake assay described in Fig. 2. FCCP, DNP or DCCD caused no significant change in either activity. With $100 \mu \mathrm{M}-$ DCCD, we observed a complete inhibition of nitrogen fixation, a process strictly dependent on ATP. Nitrate uptake was also totally inhibited by $1 \mathrm{~mm}$-azide or cyanide, the latter being an inhibitor of nitrate reductase activity both in vitro and in situ (Guerrero et al., 1973; Llobell et al., 1984). 
The utilization of nitrate by the cyanobacterium Anacystis nidulans was hindered by $10 \mu \mathrm{M}$ FCCP or DCCD, compounds that are inhibitors of ATP-requiring reactions in Anacystis nidulans (Flores et al., 1983). Nitrate uptake by the photosynthetic bacterium Rhodopseudomonas capsulata was completely and rapidly inhibited by $0.46 \mu \mathrm{M}-\mathrm{FCCP}$ (Jackson et al., 1981). In $A$. chroococcum nitrate consumption was much less sensitive to these inhibitors, with inhibition ranging from $25-35 \%$ for $10 \mu \mathrm{M}-\mathrm{FCCP}, 85-95 \%$ for $25 \mu \mathrm{M}-\mathrm{FCCP}$, and $10-20 \%$ for $100 \mu \mathrm{M}-$ DCCD. FCCP at $25 \mu \mathrm{M}$ acted as an uncoupler since aerobic respiration increased in its presence.

In general, inhibitors which decrease assimilatory nitrate uptake are those which affect energy metabolism. Inhibition of nitrate assimilation by uncouplers has been described in a variety of micro-organisms (Hofman, 1972; Schloemer \& Garrett, 1974; Jackson et al., 1981; Flores et al., 1983; Cresswell \& Syrett, 1981; Ullrich, 1974, 1983; Larsson \& Andersson, 1982). Since DCCD had no effect on nitrate uptake whereas the proton-conducting uncouplers FCCP and DNP were strongly inhibitory, the energy required for nitrate uptake may not depend directly on ATP hydrolysis but rather on a proton electrochemical gradient generated by the respiratory chain. In fact, the uncoupler-sensitive assimilatory nitrate uptake by the photosynthetic bacterium $R$. capsulata (Jackson et al., 1981), referred to above, was dependent on a proton electrochemical gradient across the plasma membrane. Alternatively, the uncouplers may inhibit indirectly by preventing ATP synthesis. Cresswell \& Syrett (1981) have interpreted the inhibition of nitrate uptake by CCCP in the diatom P. tricornutum to indicate that uptake requires a supply of ATP. Except for the lack of an effect by DCCD, our results do not rule out that nitrate transport is dependent on hydrolysis of ATP. In this context, the report by Falkowski (1975) of a membrane-bound nitrate-stimulated ATPase in $S$. costatum lends support to a direct dependence of nitrate transport on ATP hydrolysis.

\section{Effect of ascorbate/PMS on nitrate assimilation}

Since ascorbate plus PMS can serve as a respiratory substrate in E. coli, thus generating an energized state of the cytoplasmic membrane (Wilson, 1974), nitrate uptake by $A$. chroococcum was measured in assay mixtures lacking a carbon source but containing the ascorbate/PMS electron-donating system as the energy source. Oxygen uptake occurred at a rate of $264 \mathrm{nmol}$ (mg protein) ${ }^{-1} \min ^{-1}, 24 \%$ of that observed with mannitol [1108 $\mathrm{nmol}$ (mg protein) ${ }^{-1} \mathrm{~min}^{-1}$ ], and was strictly dependent on the artificial electron donor system, since neither ascorbate nor PMS alone supported any oxygen consumption. Nitrate uptake by $A$. chroococcum was observed in the presence of ascorbate/PMS (Table 2). Thus this non-physiological substrate could fulfil the energy requirement of the cell for nitrate uptake from the external medium. These results indicate that electron transport from ascorbate/PMS to oxygen generates an electrochemical gradient that can be used for the assimilatory nitrate uptake. Reduced PMS was unable to act as an electron donor for spinach nitrate reductase (Paneque et al., 1965) and probably behaves similarly towards the bacterial enzyme. The ascorbate/PMS-supported nitrate uptake by $\boldsymbol{A}$. chroococcum did not take place under anaerobic conditions or in the presence of the uncoupler FCCP. Therefore if nitrate was reduced by the electron transport chain using reducing equivalents from the artificial substrate, it is clear that the energy required for the uptake process was used to transport nitrate into the cell.

$A$. chroococcum glutamine synthetase is very sensitive to oxygen radical species such as hydroxyl radicals (Paneque $e t$ al., 1982), and Levine $e$ t al. (1981) have described inactivation of both $E$. coli and $K$. pneumoniae glutamine synthetase by an activated oxygen species. Since oxidation of reduced PMS with oxygen gives rise to oxygen radical species (Nishikimi et al., 1972), we examined the effect of the ascorbate/PMS pair on nitrate reductase and, as a control, on glutamine synthetase activity. Table 2 shows that ascorbate or PMS alone had essentially no effect, that mannitol halved, and ascorbate and PMS together nearly abolished glutamine synthetase activity. Ascorbate, PMS or the ascorbate/PMS pair had no effect on cellular nitrate reductase activity (Table 2 ), in agreement with previous results obtained with reduced viologen dyes as source of the oxygen free radical species (Paneque et al., 1982; Llobell et al., 1984). 


\section{Table 2. Effect of the ascorbate/PMS pair on nitrate uptake and activities of glutamine} synthetase and nitrate reductase in $A$. chroococcum

Enzyme activities were determined in situ in samples of cell suspensions that had been assayed for nitrate uptake for $15 \mathrm{~min}$ in the presence, as indicated, of mannitol or ascorbate/PMS, and are expressed as $\mathrm{mU}$ (mg protein) ${ }^{-1}$. Other experimental conditions as for Fig. 2 and in Methods.

\begin{tabular}{lccc}
\multicolumn{1}{c}{$\begin{array}{c}\text { Energy } \\
\text { source }\end{array}$} & $\begin{array}{c}\text { Glutamine } \\
\text { synthetase }\end{array}$ & $\begin{array}{c}\text { Nitrate } \\
\text { reductase }\end{array}$ & $\begin{array}{c}\text { Nitrate uptake } \\
\text { [nmol (mg protein })^{-1} \text { min }^{-1} \text { ] }\end{array}$ \\
None & 838 & 29 & 0 \\
Mannitol & 432 & 30 & 33 \\
PMS & 805 & 29 & 0 \\
Ascorbate & 718 & 32 & 0 \\
Ascorbate/PMS & 22 & 28 & 18
\end{tabular}

In summary, our results support the participation of a nitrate-active transport system acting before the nitrate reduction step and closely linked to the cell energy metabolism. This conclusion agrees well with data obtained from kinetic analysis of nitrate transport in $K$. pneumoniae using the radioisotope ${ }^{13} \mathrm{~N}$ (Thayer \& Huffaker, 1982), which have provided evidence to support the proposal that in bacteria nitrate transport is necessary for nitrate assimilation.

We are grateful to Professor M. Losada for his interest and encouragement, and Dr J. A. Bárcena for a critical reading of the manuscript. This work was aided by grants from Comisión Asesora de Investigación Científica y Técnica (Spain). The secretarial assistance of Pepa Pérez de León and Antonia Friend is deeply appreciated.

\section{REFERENCES}

Betlach, M. R., Tiedje, J. M. \& Firestone, R. B. (1981). Assimilatory nitrate uptake in Pseudomonas fluorescens studied using nitrogen-13. Archices of Microbiology 129, 135-140.

Cawse, P. A. (1967). The determination of nitrate in soil solution by ultraviolet spectrophotometry. Analyst 91, 311 .

Cejudo, F. J., de la Torre, A.\& Paneque, A. (1984). Short-term ammonium inhibition of nitrogen fixation in Azotobacter. Biochemical and Biophysical Research Communications 123, 431-437.

Cresswell, R. C. \& Syrett, P. J. (1981). Uptake of nitrate by the diatom Phaeodactylum tricornutum. Journal of Experimental Botany 32, 19-25.

Falkowski, P. G. (1975). Nitrate uptake in marine phytoplankton: (nitrate-chloride)-activated ATPase from Skeletonema costatum (Bacillariophyceae). Journal of Phycology 11, 323-326.

Flores, E., Guerrero, M. G. \& Losada, M. (1983). Photosynthetic nature of nitrate uptake and reduction in the cyanobacterium Anacystis nidulans. Biochimica et biophysica acta 722, 408-416.

Guerrero, M. G., Vega, J. M., Leadbetter, E. \& LOSADA, M. (1973). Preparation and characterization of a soluble nitrate reductase from Azotobacter chroococcum. Archit für Mikrobiologie 91, 287-304.

HaRold, F. M., BaARDa, J., Baron, C. \& Abrams, A. (1969). Inhibition of membrane-bound adenosine triphosphatase and of cation transport in Streptococcus faecalis by $N, N^{\prime}$-dicyclohexylcarbodiimide. Journal of Biological Chemistry 244, 2261-2268.

HaYashi, S. \& Lin, E. C. C. (1965). Capture of glycerol by cells of Escherichia coli. Biochimica et biophysica acta $94,479-487$.
Hofman, A. (1972). Über die energetische Kopplung der Nitratassimilation von Grünalgen an Atmung und Photosynthese. Planta 102, 72-84.

JaCKSON, M. A., JaCKSON, J. B. \& Ferguson, S. J. (1981). Direct observation with an electrode of uncoupler sensitive assimilatory nitrate uptake by Rhodopseudomonas capsulata. FEBS Letters 135 , 275- 278 .

KaTOH, T. (1963). Nitrate reductase in the photosynthetic bacterium, Rhodospirillum rubrum. Adaptive formation of nitrate reductase. Plant and Cell Physiology 4, 199-215.

LARSSON, C.-M. \& ANDERSSON, M. (1982). Uptake and photoreduction of $\mathrm{NO}_{3}^{-}$and $\mathrm{NO}_{-}^{-}$in Scenedesmus: interaction with $\mathrm{CO}_{2}$ fixation. In Photosynthesis, vol. IV, pp. 741-750. Edited by G. Akoyunogly. Philadelphia: Balaban International Science Services.

Levine, R., Oliver, C. N., Fulks, R. M. \& Stadtman, E. R. (1981). Turnover of bacterial glutamine synthetase oxidative inactivation precedes proteolysis. Proceedings of the National Academy of Sciences of the United States of America 78, 2120-2124.

Llobell, A., Barcena, J. A., Revilla, E. \& Paneque, A. (1984). Inactivating effect of hydrogen peroxide on nitrate reductase from Azotohacter chroococcum. Biochemistry International 9, 273-280.

MORPETH, F. F. \& BOXER, D. H. (1985). Kinetic analysis of respiratory nitrate reductase from Escherichia coli K12. Biochemistry 24, 40-46.

Nishikimi, M., RaO, N. A. \& Yagi, K. (1972). The occurrence of superoxide anion in the reaction of reduced phenazine methosulfate and molecular oxygen. Biochemical and Biophysical Research Communications 86, 849-854. 
Padan, E., Zilberstein, D. \& Rottenberg, H. (1976). The proton electrochemical gradient in Escherichia coli cells. European Journal of Biochemistry 63, 533541.

Paneque, A., Del Campo, F. F., Ramirez, J. M. \& LOSADA, M. (1965). Flavin nucleotide nitrate reductase from spinach. Biochimica et biophysica acta 109 , $79-85$.

Paneque, A., Barcena, J. A., Cordero, N., Revilla, E. \& Llobell, A. (1982). Benzyl viologen-mediated in vivo and in vitro inactivation of glutamine synthetase in Azolobacter chroococcum. Molecular and Cellular Biochemistry 92, 33-4I.

Revilla, E., Llobell, A. \& Paneque, A. (1985). The assimilatory nitrate uptake in Azotobacter chroococcum. Induction by nitrate and by cyanate. Journal of Plant Physiology 118, 165-176.

Schloemer, R. H. \& Garretr, R. H. (1974). Nitrate transport system in Neurospora crassa. Journal of Bacteriology 18, 259-269.

Serra, J. L., Llama, M. J. \& Cadenas, E. (1978). Nitrate utilization by the diatom Skeletonema costatum. 1. Kinetics and nitrate uptake. Plant Physiology 62, 987-990.
ShapiRo, B. \& StadtMan, E. R. (1970). The regulation of glutamine synthesis in microorganisms. Annual Review of Microbiology 24, 501-524.

SNell, F. D. \& SNeLl, C. T. (1949). Colorimetric Methods of Analysis, vol. 3, pp. 804-805. New York: Van Nostrand.

SYRETT, P. J. (1981). Nitrogen metabolism of microalgae. Canadian Bulletin of Fisheries and Aquatic Sciences 210, 182-210.

THAYER, J. R. \& HuffakeR, R. C. (1982). Kinetic evaluation, using ${ }^{13} \mathrm{~N}$, reveals two assimilatory nitrate transport systems in Klebsiella pneumoniae. Journal of Bacteriology 149, 198-202.

ULLRICH, W. R. (1974). Der nitrat- und nitritabhangige photosynthetische $\mathrm{O}_{2}$-Emtwicklung in $\mathrm{N}_{2}$ bei Ankistrodesmus braunii. Planta 116, 143-152.

ULLRICH, W. R. (1983). Uptake and reduction of nitrate: algae and fungi. In Encyclopedia of Plant Physiology, vol. 15, pp. 276-298. Edited by A. Laüchli \& R. L. Bieleski. Berlin, Heidelberg \& New York: Springer Verlag.

WILSON, D. B. (1974). Source of energy for the Escherichia coli galactose transport systems induced by galactose. Journal of Bacteriology 120, 866-871. 